\title{
Technology Accaptance Model to Analyze Internet Banking Reception
}

\author{
Muchriana Muchran, Harryanto, and Mediaty
}

\begin{abstract}
The research aimed to analyze trust, awareness of service, perceived ease of use, perceived usefulness and the intention to use experience. The research was conducted in Bank of Makassar, Indonesia. The data were obtained using questionnaire given to customers. The populations were customers of Bank listed as service users of Internet banking. The sample was selected using simple random sampling method. The hypotheses were tested using of Structural Equational Modeling (SEM) method by means of AMOS program. The results of the research indicate the that among the eleven hypotheses, six of them are significant, while the other five not significant. Trust has a significant relationship with to perceived ease of use. Trust does not have a significant relationship with perceived usefulness. Trust has a significant relationship with intention to use. Awareness of service has a significant relationship with perceived ease of use. Awareness of service has a significant relationship with perceived usefulness. Awareness of service does not have a significant relationship with intention to use. Perceived ease of use has a significant relationship with perceived usefulness. Perceived usefulness does not have a significant relationship with intention to use. Perceived ease of use has a significant relationship with intention to use modernized by experience. Perceived usefulness does not have a significant relationship with intention to use modernized by experience.
\end{abstract}

Index Terms-Internet banking, technology acceptance model.

\section{INTRODUCTION}

Along with the increasingly sophisticated and modern variety of technology, internet use is increasingly widespread use in various aspects of life. The existence of the internet contributes greatly to society, companies, industries and governments. The banking world is no different from other industries where internet services are being used [1]. Increased competition and effort for operational costs as efficiently as possible for banks to do a lot of innovation [2]. The banking application of concern today is internet banking.

Internet banking first appeared in the United States in the mid-1990s, where financial institutions in the United States introduced and promoted internet banking to provide better banking services [3]. Internet banking is one of the banking services that apply information technology. Internet banking

Manuscript received December 28, 2017; revised February 26, 2018.

Muchriana Muchran is with Hasanuddin University of Makassar and Muhammadiyah University of Makassar, Indonesia (e-mail: muchranmuhriana@gmail.com).

Harryanto was with Hasanuddin University of Makassar, Indonesia. He is now with the Department of Economic \& Business, Indonesia (e-mail: Harryanto@fe.unhas.ac.id).

Mediaty is with the Hasanuddin University of Makassar, Indonesia. He is now with the Department of Economic \& Business, Indonesia (e-mail: mediaty@unhas.ac.id). will not work if it is not supported by a tool as a medium to make transactions.

The increase of users of this service is increasing from year to year. Internet Banking opens new paradigms, structures and strategies for retail banks in the face of new opportunities and challenges. In Internet Banking, the physical separation between the bank and its customers and the lack of physical interaction between the customer and the bank's employees leads to a unique situation.

Although various benefits have been offered through the use of internet banking, some customers prefer to queue at banks or use ATMs (Automated Teller Machines) to conduct banking transactions when they are enabled to use internet banking. The level of acceptance of internet banking services by customers can be influenced by several factors. The studies show that the cause of the lack of intention of the customer is more on the aspect behavior [4]. To understand behavioral determinants, behavioral theory needs to be used.

Some researchers compare three theories of behavior, namely: technology acceptance model (TAM), Theory of Reasoned Action (TRA) and theory of planned behavior (TPB). Davis, F.D., Bagozzi., dan Warshaw [5] found that TAM was better at explaining the willingness to accept technology than TRA.

Chau and $\mathrm{Hu}[6]$ also compared these three models and the results showed that TAM better explain the use of technology than described by TPB. Of the several studies comparing the theory of behavior, it was found that TAM better explain the desire to rejoice technology.

The purpose of the study was to determine whether trust \& awareness of service influenced the acceptance of internet banking use by using TAM model and experience as intervening variable. The benefits of this research that can be useful to provide input for the bank in conducting customer education so that the number of internet banking users in the future can be improved again. The factors studied can be one of the consideration in taking the next policy. The next manuscript can be used as a basic reference for subsequent research, especially research interested in the theme of information technology acceptance.

\section{THEORY BASED}

\section{A. Theory of Reasoned Action (TRA)}

TRA was first coined by Ajzen in 1980 [1]. This theory is structured using the basic assumption that humans behave in a conscious way and consider all available information. In this TRA, Ajzen [7] states that the intention of a person to 
perform a behavior will determine whether or not the behavior is done (see Fig. 1).

As said, to insert images in Word, position the cursor at the Attitudes and Predicting Social Behavior. Prentice Hall. Englewood Scliffs. NJ.

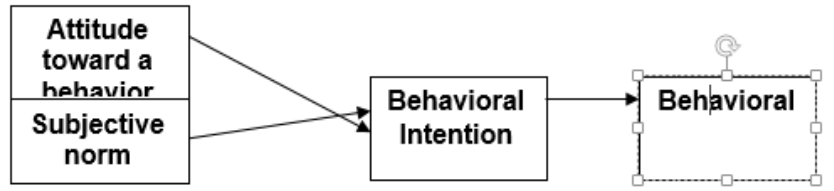

Fig. 1. Theory of reasoned action (TRA). Source : Ajzen, I., and Fishbein, M. 1980. Understanding.

\section{B. Technology Acceptance Model (TAM)}

TAM's own construct is the ease of use of perception referred to as intrinsic factor and the use of perception is called as extrinsic motivation factor in that research [8] (see Fig. 2, 3).

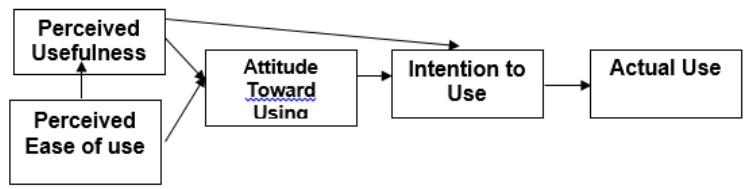

Fig. 2. Model TAM. Source: Davis 1986 [9].

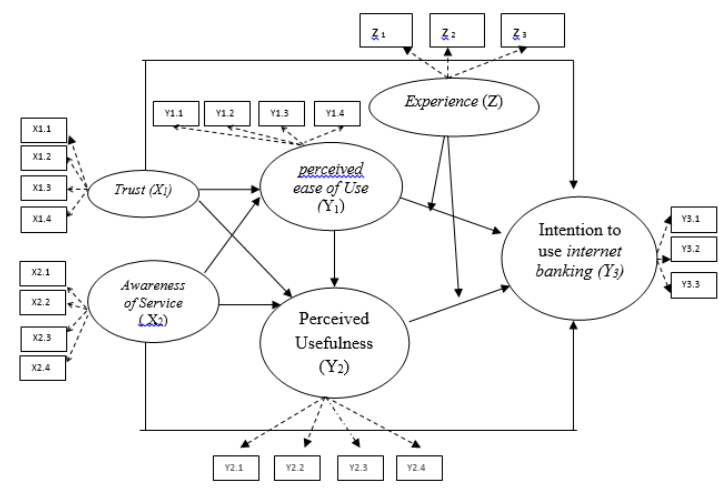

Fig. 3. Model research.

It can explicitly be restated in the form of a linear function to be estimated by simultaneous linear regression as follows:

$$
\begin{gathered}
Y_{1}=a_{0}+a_{1} X_{1}+a_{1} X_{2}+e_{1} \\
Y_{2}=\beta_{0}+\beta_{1} Y_{1}+\beta_{2} X_{1}+\beta_{3} X_{2}+e_{2} \\
Y_{3}=X_{0}+X_{1} Y_{2}+X_{2} Y_{2}+X_{3} Z_{1}+X \\
{ }_{4} Z_{2}+X_{5} X_{1}+X_{6} X_{2}+e_{3}
\end{gathered}
$$

where:

$\mathrm{Y}_{1}=$ Perceived ease of use

$\mathrm{Y}_{2}=$ Perceived usefulness

$\mathrm{Y}_{3}=$ Intention to use

$\mathrm{X}_{1}=$ Trust

$\mathrm{X}_{2}=$ Awareness of service

$\mathrm{Z}=$ Experience

$\mathrm{x}_{0}, \beta_{1}, \mathrm{a}_{2}=$ Constanta

$x_{0}, x_{1}, x_{2}, x_{3}, x_{4}, x_{5}, x_{6}, \beta_{1}, \beta_{2}, \beta_{3}, a_{1}, a_{2}$ parameters to be estimated

\section{RESEARCH METHOD}

This research is a quantitative research. Data analysis techniques in quantitative research use descriptive statistics to analyze data by way of describing or describing data that has been accumulated as it is without intending to make general conclusions or generalizations.

This research data collection using survey design by giving questionnaires to the respondents, after the respondents fill out the questionnaire, then the researcher will process the results of the questionnaire filling and explain the influence between the variables and test the hypothesis that has been formulated. In TAM research with complex models, basically can be analyzed by using regression analysis and path analysis, but in practice will be inefficient because each sub-structure must be analyzed one by one, then merged into a whole model. Such complex problems can be analyzed using Structural Equational Modeling (SEM) analysis.

\section{DISCUSSION}

\section{A. Hypothesis Testing}

Hypothesis testing research done by looking at the value of $t$ statistics of the inner model that has been formed. If the value of $t \quad$ statistics $>\quad 1.99$ then relationship between latent variables can be said significant at $\alpha=5 \%$. $\quad$ There is

\begin{tabular}{|c|c|c|c|c|c|}
\hline Hypothesis & $\begin{array}{l}\text { Directions } \\
\text { Influence } \\
\text { between } \\
\text { Variables }\end{array}$ & $\begin{array}{l}\text { Path } \\
\text { Koefisein }\end{array}$ & t-Statistic & Probability & Results \\
\hline la & $\mathrm{X}_{1} \Rightarrow \mathrm{Y}_{1}$ & 1.121 & 4.462 & 0.000 & Accepted \\
\hline lb & $\mathrm{X}_{1} \Rightarrow \mathrm{Y}_{2}$ & 0.430 & 1.580 & 0.114 & Rejected \\
\hline lc & $X_{1} \Rightarrow Y_{3}$ & 1.123 & 2.908 & 0.04 & Accepted \\
\hline $2 a$ & $\mathrm{X}_{2} \Rightarrow \mathrm{Y}_{1}$ & 1.451 & 4.958 & 0.000 & Accepted \\
\hline $2 b$ & $X_{2} \Rightarrow Y_{2}$ & 0.793 & 2.392 & 0.017 & Accepted \\
\hline $2 c$ & $X_{2} \Rightarrow Y_{3}$ & 0.331 & 0.813 & 0.416 & Rejected \\
\hline $3 \mathbf{a}$ & $Y_{1} \Rightarrow Y_{2}$ & 0.596 & 3.070 & 0.002 & Accepted \\
\hline $3 \mathbf{b}$ & $\mathbf{Y}_{1} \Rightarrow \mathbf{Y}_{3}$ & 0.495 & 1.827 & 0.068 & Rejected \\
\hline 4 & $Y_{2} \Rightarrow Y_{3}$ & -0.008 & -0.039 & 0.969 & Rejected \\
\hline $5 a$ & $\begin{array}{l}Y_{1} Z=> \\
Y_{3}\end{array}$ & 0.429 & 6.618 & 0.000 & Accepted \\
\hline $5 b$ & $\begin{aligned} & \mathbf{Y}_{2} \mathbf{Z} \\
\Rightarrow & \mathbf{Y}_{3}\end{aligned}$ & 0.035 & 0.972 & 0.331 & Rejected \\
\hline
\end{tabular}
eleven hypotheses to be answered in this study, and the results of hypothesis testing are as follows:

TABLE I: HYPOTHESIS TESTING

Source: Testing results using AMOS program

\section{B. Effect of Trust on Perceived Ease of Use}

The results showed that trust (X1) correlated significantly with perceived ease of use (Y1). This means that the ease-of-use perspective derived from Internet Banking is influenced by a person's trust in Internet Banking. Suh and Han [10] in his study verified that trust is one of the most important determinants of internet banking customer acceptance. In addition, trust has a direct effect on perceived ease of use in the context of internet banking.

\section{Effect of Trust on Perceived Usefulness}

The results show that Trust (X1) has no significant 
relationship to perceived usefulness (Y2). McKnight, D.H., \& N.L.Chervany [11] states that there are factors that can affect consumer confidence that is perceived web vendor reputation, and perceived web site quality. Perceived web vendor reputation is an attribute given to the seller based on information from other people or sources. Perceived web site quality is the perception of the quality of the site from the service provider.

The inconsistency of the results of this study with some of the previous studies was thought to be due to the perception of site quality from the service providers. Inhibiting factors such as limited computer facilities, connections and / or servers are often down to make the customer's perception of the site and the quality of internet banking declined. The internet banking system provided by the Bank relies heavily on the network used. If the network is disturbed it will hamper the customer transaction. The frequent disruption of the network makes customers unable to optimize the use or use of internet banking, although they know the benefits in using it. The bank should improve the connection, so that the purpose of this service can be fulfilled in its entirety. Thus, trust does not affect the perceived benefits of the customer.

\section{Effect of Trust on Intention to Use}

The results show that Trust (X1) has a significant relationship to intention to use (Y3). This proves the intention of customers in using internet banking is influenced because of the sense of trust felt by the customer.

\section{E. Effect of Awareness of Service on Perceived Ease of Use}

The results show that awareness of service (X2) has significant relation to perceived ease of use (Y1). This means that the higher level of customer service awareness of Internet Banking, the easier the customer will be using Internet Banking.

\section{F. Effect of Awareness of Service on Perceived Usefulness}

The results showed that Awareness of Service (X2) has a significant relationship to perceived usefulness (Y2). This means that the higher the awareness of the service on Internet Banking, the customer will know the benefits of using Internet Banking

\section{G. Effect of Awareness of Service on Intention to Use}

The results show that awareness of service (X2) has no significant relationship to intention to use (Y3). The cause of inconsistency can be seen from respondent's characteristic. The result of respondent characteristic about service which often used in this research shows that the majority of respondents use internet banking for account information that is balance check and account mutation. Here proves that the respondents have realized the existence of internet banking services, but for financial transactions such as funds transfer, respondents still less use the facility, this is because the respondents consider the security aspect as a fundamental factor when using financial banking internet transactions. So even though the respondent has awareness but the intention to make transactions using internet banking is still lacking. In other words the intention of customers to receive internet banking is not because of the awareness of the services of the customers but because of the perceived confidence of customers towards internet banking. This is also consistent with hypothesis $1 \mathrm{c}$ which finds that trust influences the acceptance of internet banking.

\section{H. Effect of Perceived Ease of Use on Perceived Usefulness}

The results show that perceived ease of use (y1) has significant influence on perceived usefulness (Y2). This means that when customers feel the convenience of Internet Banking, customers will also benefit in using Internet Banking

\section{Effect of Perceived Ease of Use on Intention to Use}

The results show that perceived ease of use (Y1) has no significant relationship to intention to use (Y3). This means that the intention of someone in using internet banking is not related to perceived convenience, or in other words, even if the customer feel the ease in internet banking service is not necessarily the customer will use the internet banking services.

In the theory of motivation is known the theory of intrinsic and extrinsic motivation. TAM's own construct is the ease of use of perception referred to as intrinsic factor. Intrinsic motivation is when the nature of the work itself that makes a person motivated, the person gets satisfaction by doing the job not because of other stimuli such as status or money or it could be said to do a hobby. Characteristics of respondents in this study indicate that users have a high level of education and income. This indicates that respondents have often used technology, either while still sitting on a lecture bench or may have become a hobby, which is currently increasingly mushrooming social networking sites, which is a major factor in increasing Internet users. With frequent interaction with computers and the internet, the use of internet banking is not difficult to learn based on the experience that has been owned, so in receiving internet banking, they do not see from the convenience anymore, but from other factors.

\section{J. Effect of Perceived Usefulness on Intention to Use}

The results show that Perceived Usefulness (y2) has no significant relationship to intention to use (Y3). In the theory of motivation is known the theory of intrinsic and extrinsic motivation. TAM's own construct is the use of perception is called extrinsic motivation factor. Extrinsic motivation is when the out-of-work element- element attached to the job becomes the main factor that motivates a person such as status or compensation.

The status of respondents in this study dominant employees as well as customers at the bank BNI, so the intention to use internet banking begins with extrinsic factors. This is why this study concludes that the intention of using internet banking by customers is not because of perceived benefits but a necessity of the workplace.

\section{K. Effect of Perceived Ease of Use on Intention to Use Which Is Moderated by Experience}

The results show that Perceived ease of use has a significant relationship to Intention to use that is moderated by Experience. This means that ease of perceived customers in using internet banking will affect the intention in using 
internet banking when the customer already has experience with information technology.

\section{Effect of Perceived Usefulness on Intention to Use Which Is Moderated by Experience}

Perceived usefulness has no significant relationship to Intention to use that is moderated by Experience. This inconsistency, probably due to the connection speed and security of internet banking services. Frequent slow connections make customers feel unbearable and get information optimally. Security is also an important factor in the use of internet banking. Bad experience both from personal and from the people around when transacting financial via internet to make the user does not come back to visit the website. It can be concluded that, although the user has experience but does not moderate the perception of benefits against intent because there are several factors such as transaction security and network speed.

\section{CONCLUSION}

Trust has significant effect on Perceived Ease of Use. Trust has no significant effect on Perceived Usefulness. Trust has significant effect on Intention to Use. Awareness of service has a significant effect on Perceived Ease of Use. Awareness of service has a significant effect on Perceived Usefulness. Awareness of service has no significant effect on Intention to Use.

Perceived ease of use has significant effect on Perceived usefulness. Perceived ease of use has no significant effect on Intention to use. Perceived usefulness have no significant effect on Intention to use. Perceived ease of use has significant effect on Intention to use that is moderated by Experience. Perceived usefulness is not significant to Intention to use that is moderated by Experience.

Based on the above conclusions, it is suggested in the next research to get a research model supported by strong empirical theory it is suggested to further reproduce other research reference in the field of internet banking. Several new variables can be added in subsequent research to get different prediction results. To get a better generalization results it is recommended for further research to take the number of respondents more.

\section{REFRENCE}

[1] I. Ajzen and M. Fishbein, Understanding Attitudes and Predicting Social Behavior, Prentice-Hall, Englewood-Cliffs, NJ, 1980.

[2] W. Ratih, "Analisis Technology Acceptance Model (TAM) terhadap factor-faktor yang mempengaruhi penerimaan nasabah terhadap layanan internet banking (Studi Empiris terhadap nasabah Bank di Depok)," Jurnal Akuntansi, fakultas ekonomi-Universitas Gunadarma, 2009.
[3] S. C. Chan and M. Lu, "Understanding internet banking adoption and use behavior: A hongkong perspective," Journal of Global Information Management, vol. 12, iss.3, p. 21, 2004.

[4] H. M. Jogiyanto, "Sistem Informasi Keprilakuan," Yogyakarta: Penerbit ANDI, 2008.

[5] F. D. Davis et al., "User acceptance of computer technology: A comparison of two theoritical models," Management Science, 1989.

[6] C. Hu, "Examining a model of information technology accaptance by individual professionals: An exploratory study," Journal of Management Information Systems, 2002.

[7] I. Ajzen, Attitudes, Personality, \& Behaviour, Dorsey Press, Chicago, 1988.

[8] F. D. Davis et al., "Extrinsic and intrinsic motivation to use computers in the workplace," Journal of Applied Social Psychology, vol. 22, no. 14, pp. 1111-1132, 1992.

[9] F. D. Davis, "Technology accaptance model for empirically testing new end-user information systems theory and results," Unpublished doctoral dissertation, MIT, 1986.

[10] S. Han, "Effect of trust on customer acceptance of Internet banking," Electronic Commerce Research and Applications, 2002.

[11] D. H. McKnight and N. L. Chervany, "What trust means in e-commerce customer relationship: An interdisciplinary conceptual typology," Journal of Electronic E-Commerce, vol. 6, no. 2, pp. 35-60, 2001.

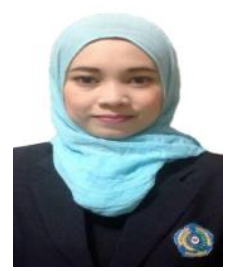

Muchriana Muchran was born on 30 September, 1988, Ujung Pandang, Indonesia. She got the undergraduate degree at Hasnauddin University of Makassar, Indonesia, majoring in accounting; the master degree at Hasanuddin University of Makassar, Indonesia; the level of accounting profession at Hasanuddin University of Makassar. Then, Since 2014-present, while the doctoral degree, major economics of accounting constancy at Hasanuddin University of Makassar.

She works as a lecturer at the Muhammadiyah University of Makassar since 2013 majoring in accounting. The last publication in 2016 under the title "Ratio to Audit Report Leg" in NFCT-STIEM International Conference, Makassar, Indonesia.

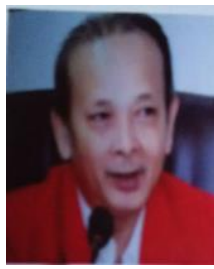

Harryanto was born on 10 Desember 1953, Indonesia. He got the undergraduate level takes the field of management study at Hasanuddin University of Makassar, Indonesia. Then, continued his masters degree at Wollonggong University, Australia majoring in accounting with M.Com degree and continued doctoral studies of accounting faculty and school of business yeop abdullah postgraduate program at Utara

University of Malaysia.

He works as a lecturer at Hasanuddin University of IMakassar and has published various journals on government accounting, public budgeting, management control and accounting behavior.

Dr. Hariyanto has collaborated on research and dedication with programs from world bank, local governance support program, asian development program of finance ministry, bappenas, local government and some observer institution of implementation of regional autonomy.

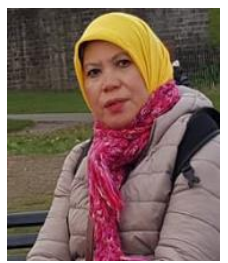

Mediaty was born on 15 September 1965, Indonesia. She got the undergraduate level at Hasanuddin University of Makassar, Indonesia. Then, continued his masters degree at Gadjah Mada University of Indonesia, and continued doctoral studies of Hasanuddin University,Indonesia.

She works as a lecturer at Hasanuddin University of Makassar, Indonesia and has published various journals on management accounting.

Prof. Mediaty is the head of the Accounting Department of Faculty of Economics and Business Hasanuddin University of Makassar, Indonesia since 2014 until now. 